\title{
Potential Use of Jackfruit (Artocarpus Heterophyllus) and Breadfruit (Artocarpus Altilis) as Fat Replacer to Produce Low-Fat Chicken Patties
}

\author{
Mohammad Rashedi Ismail-Fitry ${ }^{1 *}$, Nur Farihah Azwa Abas ${ }^{1}$ \\ ${ }^{1}$ Department of Food Technology, Faculty of Food Science and Technology, Universiti Putra Malaysia 43400 UPM Serdang, Selangor, \\ Malaysia \\ *Corresponding author E-mail: ismailfitry@upm.edu.my
}

\begin{abstract}
Commercial chicken patties contain high fat, which could affect consumers' health. Jackfruit (Artocarpus heterophyllus) and breadfruit (Artocarpus altilis) may have the potential to be used as the fat replacer in the chicken patties. This study aimed to evaluate the low-fat chicken patties produced by replacing the fat with jackfruit (JF) or breadfruit (BF) at $0 \%$ (control), 50\% and $100 \%$. The samples were analysed in terms of water holding capacity (WHC), cooking yield (CY), proximate analysis, colour, texture properties, and sensory parameters. Both BF and JF showed higher value $(\mathrm{p}<0.05)$ for WHC, moisture content and protein compared to the control. BF $(100 \%)$ and $\mathrm{JF}(100 \%)$ were recorded of having significantly reduced fat $(\mathrm{p}<0.05)$ at $1.80 \%$ and $2.23 \%$, respectively. BF showed higher $\mathrm{L}^{*}($ lightness) and $b^{*}$ (yellowness) values significantly $(p<0.05)$ compared to the control. Not many significant differences $(p>0.05)$ between the control and newly formulated chicken patties texture based on the hardness, cohesiveness, and chewiness recorded, proving that BF and JF did not affect the patties texture. Overall, the sensory evaluation of BF (100\%) was preferred by the consumer in terms of appearance, texture, flavour, juiciness, and aroma. Thus, $\mathrm{BF}(100 \%)$ can be considered as the best fat replacer in this study.
\end{abstract}

Keywords: chicken patties; jackfruit; breadfruit; fat replacer; low-fat.

\section{Introduction}

Different types of meat such as beef, mutton, buffalo and poultry have been processed into products and widely studied such as nuggets [1], patties [2], jerky [3], meatballs [4], etc. More people are concerned about their health and tend towards healthier food products for consumption. Therefore, they might consider that the meat products as unhealthy food since meat products contain high fat content.

Meat fat functions as a reservoir for flavour and binder to maintain the texture of meat products [5]. Many researchers are trying to find an alternative that associated with the reduction of fat in meat products. However, it might be difficult to find an effective and functional fat replacer since reducing the fat content in meat products leads to the alteration of the flavour and other important characteristics such as its juiciness and colour [6].

Fat replacers are the ingredients that contribute fewer or no calories to the formulated foods without changing any important characteristics and organoleptic properties of the products [7]. Various ingredients are being used to replace fat in meat products such as carbohydrates and starches [8], protein [9] and fibre [10].

Jackfruit and breadfruit are local fruits that rich in protein, starch, calcium, and thiamine. Jackfruit and breadfruit might be potential to be used as fat replacer because of their functional properties and ability to corporate with meat products. Therefore, the objectives of this study were to produce low-fat chicken patties with jackfruit and breadfruit as the fat replacer and study the physiochemical and sensory properties of the new formulated low-fat chicken patties.

\section{Materials and Methods}

\subsection{Sample preparation}

The chicken breast meat, fat and unripe jackfruits were purchased from Pasar Borong Selangor, while, the pre-matured breadfruits were provided by Taman Pertanian Universiti, UPM. Salt, sugar, minced garlic, sodium tripolyphosphate (STPP) and isolated soy protein (ISP) were obtained from the local supplier.

In the preparation of the samples, the chicken breast meats were minced using a mincer machine (Hobart 4822, USA). The jackfruit and breadfruit were boiled for forty minutes and then, minced by using a blender (Panasonic MX-SM 1031, Malaysia). The replacement of jackfruit and breadfruit as fat in chicken patties were carried out in a paste form.

The fat content represents $20 \%$ of the total amount of the chicken patties ingredients. Five formulations of chicken patties were prepared for the experiment with triplicates (Table 1).

\begin{tabular}{cccccc}
\multicolumn{6}{c}{ Table 1: Formulation of fat-replaced chicken patties } \\
\hline \multirow{2}{*}{ Ingredients } & $\begin{array}{c}100 \% \text { fat } \\
\text { (Control) }\end{array}$ & $\begin{array}{c}50 \% \\
\text { jackfruit }\end{array}$ & $\begin{array}{c}100 \% \\
\text { jackfruit }\end{array}$ & $\begin{array}{c}50 \% \\
\text { breadfruit }\end{array}$ & $\begin{array}{c}100 \% \\
\text { breadfruit }\end{array}$ \\
\hline Chicken & $70 \%$ & $70 \%$ & $70 \%$ & $70 \%$ & $70 \%$ \\
Fat & $20 \%$ & $10 \%$ & $0 \%$ & $10 \%$ & $0 \%$ \\
Jackfruit & $0 \%$ & $10 \%$ & $20 \%$ & $0 \%$ & $0 \%$ \\
Breadfruit & $0 \%$ & $0 \%$ & $0 \%$ & $10 \%$ & $20 \%$ \\
Ice water & $4.4 \%$ & $4.4 \%$ & $4.4 \%$ & $4.4 \%$ & $4.4 \%$ \\
Sugar & $1.0 \%$ & $1.0 \%$ & $1.0 \%$ & $1.0 \%$ & $1.0 \%$ \\
Salt & $1.5 \%$ & $1.5 \%$ & $1.5 \%$ & $1.5 \%$ & $1.5 \%$ \\
\hline
\end{tabular}




\begin{tabular}{cccccc} 
Garlic & $0.7 \%$ & $0.7 \%$ & $0.7 \%$ & $0.7 \%$ & $0.7 \%$ \\
STPP & $0.4 \%$ & $0.4 \%$ & $0.4 \%$ & $0.4 \%$ & $0.4 \%$ \\
ISP & $2.0 \%$ & $2.0 \%$ & $2.0 \%$ & $2.0 \%$ & $2.0 \%$ \\
Total & $100 \%$ & $100 \%$ & $100 \%$ & $100 \%$ & $100 \%$ \\
\hline
\end{tabular}

They were the control with $100 \%$ fat (20\% fat of the ingredients), $50 \%$ jackfruit as fat replacer $(10 \%$ fat and $10 \%$ jackfruit of the ingredients), $100 \%$ jackfruit as fat replacer $(20 \%$ jackfruit of the ingredients), $50 \%$ breadfruit as fat replacer (10\% fat and $10 \%$ breadfruit of the ingredients), and $100 \%$ breadfruit as fat replacer ( $20 \%$ breadfruit of the ingredients).

\section{2. $\mathrm{pH}$ value}

Ten $\mathrm{g}$ of sample was mixed with $10 \mathrm{~mL}$ of distilled water. Then, the $\mathrm{pH}$ value was measured by using $\mathrm{pH}$ meter (Jenway 3505, England).

\subsection{Water holding capacity (WHC)}

WHC was determined according to Dosh et al. [11] with some modifications. Ten $\mathrm{g}$ of sample was mixed with $20 \mathrm{~mL}$ of distilled water by using homogenizer (Heidolph Diax 900, USA). Then, it was centrifuged (KUBOTA 5800, Japan) at $1500 \mathrm{rpm}$ for $5 \mathrm{~min}-$ utes. The WHC of the sample was determined by using the following formula:

WHC $(\%)=[($ water weight before centrifuge $)-($ water weight after centrifuge $)] /[$ (sample weight $)] \times 100$

\subsection{Cooking yield}

The estimation of cooking yield was carried based on the method described by Guedes-Oliveira et al. [12] as follows:

Cooking yield $(\%)=[($ Final weight of sample $) /($ Initial weight of sample)] x 100

\subsection{Proximate analysis}

The proximate compositions of the chicken patties such as moisture, ash, protein, and fat were determined by using the AOAC method [13], while the carbohydrate contents were obtained by the differences.

\subsection{Colour measurement}

The colour measurement of chicken patties was evaluated by placing the transparent packaging plastic on $5 \mathrm{~cm}$ diameter of sample. Then, the rates of lightness $\left(\mathrm{L}^{*}\right)$, redness $\left(\mathrm{a}^{*}\right)$, and yellowness $\left(\mathrm{b}^{*}\right)$ of samples were obtained by using chromameter (Konica Minolta, Japan).

\subsection{Texture profile analysis (TPA)}

TPA was determined by using a computer-assisted, Stable Micro Systems Texture analyzer (TA.XT-Plus, London). The samples were examined by using a probe, $75 \mathrm{~mm}$ square compression platen type. The hardness, cohesiveness, springiness, and chewiness of chicken patties were measured. The texture analyser settings for TPA were: load cell at $25 \mathrm{~kg}$, pre-test speed at 1.00 $\mathrm{mm} / \mathrm{sec}$, test speed at $1.00 \mathrm{~mm} / \mathrm{sec}$, the post-test speed at 5.00 $\mathrm{mm} / \mathrm{sec}$, and strain at $70 \%$.

\subsection{Sensory evaluation}

The samples were grilled at $70^{\circ} \mathrm{C}$ for 5 minutes each side before served to thirty untrained panellists. The sensory evaluation was carried out by using a nine-point hedonic scale to evaluate the texture, flavour, appearance, aroma, juiciness and overall acceptability. The hedonic scales were as follows: 9 - like extremely, 8 - like very much, 7 - like moderately, 6 - like slightly, 5 - neither dislike or like, 4 - dislike slightly, 3 - dislike moderately, 2 dislike very much, and 1 - dislike extremely [12].

\subsection{Statistical analysis}

The data from three replications of the two factors (types of fat replacer and concentration) were analysed by two-way ANOVA and Turkey's test with a significance level of $95 \%(\mathrm{p}<0.05)$ by using statistical software, Minitab Statistical Software version 16 (MiniTab Inc., USA).

\section{Results and Discussion}

\section{1. $\mathrm{pH}$ value, water holding capacity and cooking yield}

Table 2 shows the result of the $\mathrm{pH}$ value, water holding capacity and cooking yield of the chicken patties. Two factors were compared; the concentrations and types of fat replacer. The results show that the $\mathrm{pH}$ of samples with the concentration of $50 \%$ and $100 \%$ fat replacement were significantly reduced $(\mathrm{p}<0.05)$ as compared to the control for both JF and BF. BF resulted in lower $\mathrm{pH}$ values compared to JF significantly $(\mathrm{p}<0.05)$. The results were acceptable as the $\mathrm{pH}$ values were slightly similar to the chicken patties in the study of Calliari et al. [14]. It showed that the commercial chicken patties have a $\mathrm{pH}$ value at range of 6.37 to 6.39 .

Table 2: $\mathrm{pH}$ value, water holding capacity (WHC) and cooking yield of fat-replaced chicken patties

\begin{tabular}{|c|c|c|c|c|}
\hline \multirow{2}{*}{ Analysis } & \multirow{2}{*}{$\begin{array}{c}\text { Fat } \\
\text { replacer } \\
\text { types }\end{array}$} & \multicolumn{3}{|c|}{ Fat replacer concentrations ( $\%$ ) } \\
\hline & & $0 \%$ & $50 \%$ & $100 \%$ \\
\hline \multirow{2}{*}{$\mathrm{pH}$} & Jackfruit & $6.37 \pm 0.02^{\mathrm{Aa}}$ & $6.31 \pm 0.01^{\mathrm{Ba}}$ & $6.30 \pm 0.01^{\mathrm{Ba}}$ \\
\hline & Breadfruit & $6.37 \pm 0.02^{\mathrm{Aa}}$ & $6.27 \pm 0.01$ & $6.26 \pm 0.01$ \\
\hline \multirow{2}{*}{ WHC } & Jackfruit & $33.27 \pm 1.08^{\mathrm{Ca}}$ & $46.84 \pm 1.40^{\mathrm{Ba}}$ & $55.11 \pm 1.40$ \\
\hline & Breadfruit & $33.27 \pm 1.08^{\mathrm{Ca}}$ & $48.97 \pm 1.31^{\mathrm{Ba}}$ & $56.31 \pm 0.81$ \\
\hline \multirow{2}{*}{$\begin{array}{c}\text { Cooking } \\
\text { yield }\end{array}$} & Jackfruit & $85.01 \pm 0.16^{\mathrm{Aa}}$ & $84.37 \pm 0.58^{\mathrm{Aa}}$ & $84.90 \pm 0.21^{\mathrm{A}}$ \\
\hline & Breadfruit & $85.01 \pm 0.16^{\mathrm{Aa}}$ & $84.48 \pm 0.51^{\mathrm{Aa}}$ & $85.10 \pm 0.75^{\mathrm{A}}$ \\
\hline
\end{tabular}

Means that do not share the same letter are significantly different $(\mathrm{P}<0.05)$ within the same analysis. Capital letters are for the comparison of fat replacer concentrations (row). Small letters are for the comparison of fat replacer types (column).

Even though lower $\mathrm{pH}$ is usually associated with lower water holding capacity, the results in Table 2 show conversely. Water holding capacity is the ability of meat to hold onto water that influences in juiciness and tenderness of meat [15]. The WHC was significantly increased $(\mathrm{p}<0.05)$ when compared to the control for both $\mathrm{JF}$ and $\mathrm{BF}$ at 50 and $100 \%$ concentration. $\mathrm{BF}(100 \%)$ and $\mathrm{JF}$ $(100 \%)$ showed higher values of WHC at $56.31 \%$ and $55.11 \%$, respectively compared to the control, which was $33.27 \%$. The results most probably due to the fat that was replaced by carbohydrate/ starch and protein, which could promote water holding in the chicken patties. Study by Glicksman [16] supports this statement where the carbohydrate-based fat replacer in meat products can achieve the ability of water holding and improvement in texture.

$\mathrm{BF}$ in $100 \%$ fat-replacement also determined a higher value of cooking yields at $85.10 \%$ but the result was not significantly different $(p>0.05)$ as compared to other treatments. The result is in agreement with the reduced-fat chicken patties made with polymer from Agrobacterium radiobacter [14]. Cooking yield is a good indicator to explain the effect on WHC [15]. The results show the ability of breadfruit's component such as carbohydrate, protein and fibre that can hold the water and determine the functional properties such as its texture. 


\subsection{Proximate compositions}

The proximate compositions of fat-replaced chicken patties are shown in Table 3. Both chicken patties with $\mathrm{BF}$ and JF as fat replacers from $0 \%$ to $100 \%$ had their moisture contents increased significantly $(\mathrm{p}<0.05)$. BF with $100 \%$ replacement resulted with the highest value of moisture content at $70.59 \%$. It was probably influenced by the high moisture content in breadfruit. This was slightly similar to the study by Guedes-Oliveira et al. [12] in formulated chicken patties with cashew apple fibre. Furthermore, the jackfruit paste and breadfruit paste that were produced could carry over moisture from the boiling process.

Analysis of the ash content resulted with no significant differences between the fat replacer concentrations and types ( $p>0.05)$. No significant different $(p>0.05)$ also was observed between type of fat replacer for protein content. However, the 50\% and 100\% concentration of fat replacers used to produce chicken patties showed a significant increase in protein content $(\mathrm{p}<0.05)$ as compared to the control most probably due to the protein content of these two fruits. It showed that protein of JF $(100 \%)$ at $6.23 \%$ and BF $(100 \%)$ at $6.60 \%$, were higher than the control $(5.59 \%)$. The results were a little bit contrast as carbohydrate polymers mostly consist of fibres that have a low level of protein or ash [17].

There was a significant reduction $(p<0.05)$ of the fat contents of all the treatments from $100 \%$ fat replacer to $0 \%$ fat replacer. However, both BF and JF showed no significant different ( $\mathrm{p}>0.05)$ of the fat content when comparisons made between them. The fat content for $\mathrm{BF}$ with $100 \%$ fat replacement was reduced greatly at $1.80 \%$ compared to the control, which was $8.26 \%$. JF (100\%), which the fat content was $2.23 \%$ also reduced significantly compared to the control. Both chicken patties with BF and JF at $100 \%$ fat replacement can be claimed as the low-fat product according to Malaysian Food Regulations 1985 [18]. The results also can be compared with the study that uses jackfruit as the meat substitute in chevon patties and contributed to reducing the fat [19]. The reason for reducing fat can be directly related to low-fat content in both jackfruit [19] and breadfruit [20]. The carbohydrate content for patties with $\mathrm{BF}$ and $\mathrm{JF}$ at $50 \%$ were significantly lower $(\mathrm{p}<0.05)$ compared to $0 \%$, and $0 \%$ and $100 \%$, respectively. This can be related to the unbalanced total amount of fat and protein in the newly formulated products that influenced the carbohydrate content.

\subsection{Colour measurement and texture profile analysis}

Table 3: Proximate composition of fat-replaced chicken patties

\begin{tabular}{|c|c|c|c|c|}
\hline \multirow{2}{*}{ Proximate } & \multirow{2}{*}{$\begin{array}{l}\text { Fat } \\
\text { replacer } \\
\text { types }\end{array}$} & \multicolumn{3}{|c|}{ Fat replacer concentrations (\%) } \\
\hline & & $0 \%$ & $50 \%$ & $100 \%$ \\
\hline \multirow[t]{2}{*}{ Moisture } & Jackfruit & $\underset{\mathrm{a}}{64.10 \pm 0.33^{\mathrm{C}}}$ & $67.20 \pm 1.01^{\mathrm{B}}$ & $69.77 \pm 0.53^{\mathrm{Aa}}$ \\
\hline & $\begin{array}{l}\text { Bread- } \\
\text { fruit }\end{array}$ & $\underset{a}{64.10 \pm 0.33^{C}}$ & $\frac{68.49 \pm 1.02^{\mathrm{B}}}{\mathrm{a}}$ & $70.59 \pm 0.47^{\mathrm{Aa}}$ \\
\hline \multirow[t]{2}{*}{ Ash } & Jackfruit & $1.75 \pm 0.10^{\mathrm{Aa}}$ & $1.62 \pm 0.35^{\mathrm{Aa}}$ & $1.74 \pm 0.05^{\mathrm{Aa}}$ \\
\hline & $\begin{array}{l}\text { Bread- } \\
\text { fruit }\end{array}$ & $1.75 \pm 0.10^{\mathrm{Aa}}$ & $1.65 \pm 0.08^{\mathrm{Aa}}$ & $1.77 \pm 0.04^{\mathrm{Aa}}$ \\
\hline \multirow[t]{2}{*}{ Protein } & Jackfruit & $5.59 \pm 0.33^{\mathrm{Ba}}$ & $6.38 \pm 0.17^{\mathrm{Aa}}$ & $6.23 \pm 0.16^{\mathrm{Ab}}$ \\
\hline & $\begin{array}{l}\text { Bread- } \\
\text { fruit }\end{array}$ & $5.59 \pm 0.33^{\mathrm{Ba}}$ & $6.30 \pm 0.10^{\mathrm{Aa}}$ & $6.60 \pm 0.14^{\mathrm{Aa}}$ \\
\hline \multirow[t]{2}{*}{ Fat } & Jackfruit & $8.26 \pm 0.37^{\mathrm{Aa}}$ & $6.63 \pm 0.52^{\mathrm{Ba}}$ & $2.23 \pm 0.19^{\mathrm{Ca}}$ \\
\hline & $\begin{array}{l}\text { Bread- } \\
\text { fruit }\end{array}$ & $8.26 \pm 0.37^{\mathrm{Aa}}$ & $6.11 \pm 0.40^{\mathrm{Ba}}$ & $1.80 \pm 0.20^{\mathrm{Ca}}$ \\
\hline \multirow[t]{2}{*}{$\begin{array}{l}\text { Carbohy- } \\
\text { drate }\end{array}$} & Jackfruit & $\frac{20.27 \pm 0.53^{\mathrm{A}}}{\mathrm{a}}$ & $18.19 \pm \frac{0.36^{B}}{B}$ & $20.04 \pm 0.77^{\mathrm{Aa}}$ \\
\hline & $\begin{array}{l}\text { Bread- } \\
\text { fruit }\end{array}$ & $\underset{\mathrm{a}}{20.27 \pm 0.53^{\mathrm{A}}}$ & $17.45 \pm 1.33^{\mathrm{B}}$ & $\frac{19.23 \pm 0.55^{A B}}{\mathrm{AB}}$ \\
\hline
\end{tabular}

Means that do not share the same letter are significantly different $(\mathrm{P}<$ 0.05 ) within the same analysis. Capital letters are for the comparison of fat replacer concentrations (row). Small letters are for the comparison of fat replacer types (column)

The data collected from the analysis of colour measurement of chicken patties are shown in Table 4 . The optical intensity properties in terms of lightness $\left(\mathrm{L}^{*}\right)$, redness $\left(\mathrm{a}^{*}\right)$, and yellowness $\left(\mathrm{b}^{*}\right)$ were compared between the concentrations and two types of fat replacers. The colour of meat products may be attributed to the chemical state and concentration of meat pigments, the presence of non-meat ingredients and physical state of the meat that used in the formulation [21].

Table 4: Colour and texture of fat-replaced chicken patties

\begin{tabular}{|c|c|c|c|c|c|}
\hline \multirow{2}{*}{\multicolumn{2}{|c|}{ Parameters }} & \multirow{2}{*}{$\begin{array}{l}\text { Fat } \\
\text { re- } \\
\text { placer } \\
\text { types }\end{array}$} & \multicolumn{3}{|c|}{ Fat replacer concentrations $(\%)$} \\
\hline & & & $0 \%$ & $50 \%$ & $100 \%$ \\
\hline \multirow{6}{*}{$\begin{array}{l}\text { Colour } \\
\text { parame- } \\
\text { ters }\end{array}$} & \multirow{2}{*}{$\mathrm{L}^{*}$} & $\begin{array}{l}\text { Jack- } \\
\text { fruit }\end{array}$ & $\underset{1}{75.01 \pm 0.3}$ & $\begin{array}{c}74.43 \pm 0.5 \\
4\end{array}$ & $\begin{array}{c}73.47 \pm 0.8 \\
3^{\mathrm{Bb}}\end{array}$ \\
\hline & & $\begin{array}{l}\text { Bread- } \\
\text { fruit }\end{array}$ & $\begin{array}{c}75.01 \pm 0.3 \\
1\end{array}$ & $\begin{array}{c}79.08 \pm 0.4 \\
7^{\mathrm{Aa}}\end{array}$ & $\begin{array}{c}79.07 \pm 0.8 \\
4^{\mathrm{Aa}}\end{array}$ \\
\hline & \multirow{2}{*}{$a^{*}$} & $\begin{array}{l}\text { Jack- } \\
\text { fruit }\end{array}$ & $\underset{\mathrm{Aa}}{5.68 \pm 0.84}$ & $\underset{\mathrm{Aa}}{4.99 \pm 0.38}$ & $\underset{\mathrm{Ba}}{3.32 \pm 0.38}$ \\
\hline & & $\begin{array}{l}\text { Bread- } \\
\text { fruit }\end{array}$ & $\underset{\mathrm{Aa}}{5.68 \pm 0.84}$ & $\underset{\mathrm{Ab}}{4.18 \pm 0.32}$ & $\underset{\mathrm{Aa}}{4.26 \pm 0.64}$ \\
\hline & \multirow{2}{*}{$b^{*}$} & $\begin{array}{l}\text { Jack- } \\
\text { fruit }\end{array}$ & $\begin{array}{c}14.94 \pm 0.4 \\
1\end{array}$ & $\begin{array}{c}15.08 \pm 0.8 \\
\mathrm{Ab}\end{array}$ & $\underset{1}{14.81 \pm 1.0}$ \\
\hline & & $\begin{array}{l}\text { Bread- } \\
\text { fruit }\end{array}$ & $\begin{array}{c}14.94 \pm 0.4 \\
1\end{array}$ & $\underset{1}{18.44 \pm 0.7}$ & $\underset{1}{19.11 \pm 0.4}$ \\
\hline \multirow{8}{*}{$\begin{array}{l}\text { Texture } \\
\text { parame- } \\
\text { ters }\end{array}$} & \multirow{2}{*}{$\begin{array}{l}\text { Hardness } \\
(\mathrm{kg})\end{array}$} & $\begin{array}{l}\text { Jack- } \\
\text { fruit }\end{array}$ & $\begin{array}{c}14.95 \pm 0.9 \\
9\end{array}$ & $\begin{array}{c}17.36 \pm 1.4 \\
\text { Aa }\end{array}$ & $\begin{array}{c}15.48 \pm 1.6 \\
\text { Aa }\end{array}$ \\
\hline & & $\begin{array}{l}\text { Bread- } \\
\text { fruit }\end{array}$ & $\begin{array}{c}14.95 \pm 0.9 \\
9\end{array}$ & $\begin{array}{c}11.43 \pm 1.2 \\
5\end{array}$ & $\begin{array}{c}10.90 \pm 1.7 \\
3^{\mathrm{Bb}}\end{array}$ \\
\hline & \multirow{2}{*}{$\begin{array}{l}\text { Cohe- } \\
\text { siveness }\end{array}$} & $\begin{array}{l}\text { Jack- } \\
\text { fruit }\end{array}$ & $\underset{\mathrm{Aa}}{0.54 \pm 0.06}$ & $\underset{\mathrm{Aa}}{0.53 \pm 0.01}$ & $\underset{\mathrm{Aa}}{0.48 \pm 0.03}$ \\
\hline & & $\begin{array}{l}\text { Bread- } \\
\text { fruit }\end{array}$ & $\underset{\mathrm{Aa}}{0.54 \pm 0.06}$ & $\underset{\mathrm{Bb}}{0.40 \pm 0.05}$ & $\underset{\mathrm{Bb}}{0.39 \pm 0.03}$ \\
\hline & \multirow{2}{*}{$\begin{array}{l}\text { Springi- } \\
\text { ness }\end{array}$} & $\begin{array}{l}\text { Jack- } \\
\text { fruit }\end{array}$ & $\underset{\mathrm{Aa}}{0.81 \pm 0.06}$ & $\underset{\mathrm{Aa}}{0.84 \pm 0.03}$ & $\underset{\mathrm{Aa}}{0.78 \pm 0.03}$ \\
\hline & & $\begin{array}{l}\text { Bread- } \\
\text { fruit }\end{array}$ & $\underset{\mathrm{Aa}}{0.81 \pm 0.06}$ & $0.77 \pm \underset{\mathrm{Ab}}{ \pm 0.01}$ & $\underset{\mathrm{Aa}}{0.81 \pm 0.01}$ \\
\hline & \multirow{2}{*}{$\begin{array}{l}\text { Chewi- } \\
\text { ness } \\
(\mathrm{kg} / \mathrm{mm})\end{array}$} & $\begin{array}{l}\text { Jack- } \\
\text { fruit }\end{array}$ & $\underset{\mathrm{Aa}}{6.62 \pm 1.30}$ & $\underset{\mathrm{Aa}}{7.73 \pm 1.03}$ & $\underset{\mathrm{Aa}}{5.83 \pm 0.85}$ \\
\hline & & $\begin{array}{l}\text { Bread- } \\
\text { fruit }\end{array}$ & $\underset{\mathrm{Aa}}{6.62 \pm 1.30}$ & $\underset{\mathrm{Bb}}{3.54 \pm 0.75}$ & $\underset{\mathrm{Bb}}{3.49 \pm 0.87}$ \\
\hline
\end{tabular}

Means that do not share the same letter are significantly different $(\mathrm{P}<0.05)$ within the same analysis. Capital letters are for the comparison of fat replacer concentrations (row). Small letters are for the comparison of fat replacer types (column).

$\mathrm{BF}$ at $50 \%$ and $100 \%$ showed higher lightness $\left(\mathrm{L}^{*}\right)$ and yellowness $\left(b^{*}\right)$ values compared to other treatments $(p<0.05)$. Meanwhile, JF at $100 \%$ showed the lowest value of redness $\left(a^{*}\right)$ $(p<0.05)$. The result of JF and BF chicken patties are slightly similar to the control of chicken patties as in the study of Calliari et al. [14]. It might be because of the colour of breadfruit's flesh is lighter and yellower than jackfruit. This conclusion is determined by observation for both fat replacers. Above all, the results showed that the newly formulated chicken patties with jackfruit and breadfruit are in an acceptable colour range when referred to the commercial chicken patties [14]

TPA of chicken patties was measured based on hardness, cohesiveness, springiness, and chewiness (Table 4). BF (100\%) resulted in the lowest value of hardness $(10.90 \mathrm{~kg})$ compared to the control $(14.95 \mathrm{~kg})$. The concentration of $50 \%$ and $100 \%$ were significantly different $(\mathrm{p}<0.05)$ with control $(0 \%)$ and the hardness of BF was lower $(p<0.05)$ compared to JF. This might be due to the high moisture content in BF that made it softer. Even though $\mathrm{BF}(100 \%)$ has soft texture compared to commercial chicken pat- 
ties [15], the chicken patties were accepted by human consumption due to acceptance during the sensory evaluation.

In addition, the cohesiveness and chewiness of BF (100\%) were among the lowest, which was at 0.39 and 3.49 , respectively. The results were quite similar to the study by Verma et al. [19] that showed chevon patties with jackfruit as meat substitute have soft texture compared to the control. This was also parallel with another study of low-fat pork patties with sweet potato powder and added water as fat replacer [22]. According to Jalal et al. [23], carbohydrate-based fat replacer can improve the texture of meat products because of starch composition in the fat replacers might influence the binding of water in the meat. Lastly, the springiness values of all the patties were not significantly different $(\mathrm{p}>0.05)$ among all the treatments. Therefore, $\mathrm{BF}(100 \%)$ can be concluded to have a good texture in terms of hardness, cohesiveness, springiness and chewiness as it contains a high amount of starch.

\subsection{Sensory evaluation}

Table 5: Sensory evaluation in certain parameters of chicken patties

\begin{tabular}{|c|c|c|c|c|}
\hline \multirow{2}{*}{ Parameters } & \multirow{2}{*}{$\begin{array}{c}\text { Fat } \\
\text { replacer } \\
\text { types }\end{array}$} & \multicolumn{3}{|c|}{ Fat replacer concentrations $(\%)$} \\
\hline & & $0 \%$ & $50 \%$ & $100 \%$ \\
\hline \multirow{2}{*}{ Appearance } & Jackfruit & $6.57 \pm 1.07^{\mathrm{Aa}}$ & $6.77 \pm 1.07^{\mathrm{Ab}}$ & $7.10 \pm 0.80^{\mathrm{Ai}}$ \\
\hline & Breadfruit & $6.57 \pm 1.07^{\mathrm{Ba}}$ & $7.40 \pm 0.81^{\mathrm{Aa}}$ & $7.37 \pm 0.85^{\mathrm{A}}$ \\
\hline \multirow{2}{*}{ Texture } & Jackfruit & $6.10 \pm 0.96^{\mathrm{Ba}}$ & $6.70 \pm 0.79^{\mathrm{Ab}}$ & $7.10 \pm 0.80^{\mathrm{Al}}$ \\
\hline & Breadfruit & $6.10 \pm 0.96^{\mathrm{Ca}}$ & $7.17 \pm 0.91^{\mathrm{Ba}}$ & $7.73 \pm 0.69^{\mathrm{A}_{2}}$ \\
\hline \multirow{2}{*}{ Flavour } & Jackfruit & $6.13 \pm 1.01^{\mathrm{Ba}}$ & $6.53 \pm 0.78^{\mathrm{ABb}}$ & $6.90 \pm 0.76^{\mathrm{Al}}$ \\
\hline & Breadfruit & $6.13 \pm 1.01^{\mathrm{Ba}}$ & $7.47 \pm 1.01^{\mathrm{Aa}}$ & $7.97 \pm 0.77^{\mathrm{A}}$ \\
\hline \multirow{2}{*}{ Juiciness } & Jackfruit & $6.07 \pm 0.87^{\mathrm{Ba}}$ & $6.63 \pm 0.77^{\mathrm{ABb}}$ & $7.13 \pm 1.17^{\mathrm{Al}}$ \\
\hline & Breadfruit & $6.07 \pm 0.87^{\mathrm{Ca}}$ & $7.33 \pm 0.99^{\mathrm{Ba}}$ & $8.23 \pm 0.77^{A}$ \\
\hline \multirow{2}{*}{ Aroma } & Jackfruit & $6.30 \pm 0.92^{\mathrm{Ba}}$ & $6.53 \pm 0.73^{\mathrm{ABb}}$ & $6.87 \pm 0.94^{\mathrm{Al}}$ \\
\hline & Breadfruit & $6.30 \pm 0.92^{\mathrm{Ca}}$ & $7.13 \pm 0.97^{\mathrm{Ba}}$ & $7.80 \pm 0.89^{\mathrm{A}_{i}}$ \\
\hline \multirow{2}{*}{ Overall } & Jackfruit & $6.23 \pm 1.01^{\mathrm{Ba}}$ & $6.80 \pm 0.66^{\mathrm{Ab}}$ & $7.00 \pm 0.87^{\mathrm{Al}}$ \\
\hline & Breadfruit & $6.23 \pm 1.01^{\mathrm{Ba}}$ & $7.60 \pm 0.86^{\mathrm{Aa}}$ & $8.10 \pm 0.71^{\mathrm{A}=}$ \\
\hline
\end{tabular}

Means that do not share the same letter are significantly different $(\mathrm{P}<0.05)$ within the same analysis. Capital letters are for the comparison of fat replacer concentrations (row). Small letters are for the comparison of fat replacer types (column).

Chicken patties with $\mathrm{BF}(100 \%)$ as fat replacer obtained positive acceptance by panellists as shown in Table 5 . It showed that BF $(100 \%)$ scored the highest value $(\mathrm{p}<0.05)$ in each parameter (appearance, texture, flavour, juiciness, and aroma) compared to other treatments. For overall sensory result, BF $(100 \%)$ showed the best value which was at 8.10 compared to $\mathrm{JF}(50 \%$ and $100 \%)$ and control. Similar to the results, a study on dry fermented sausages formulated with orange fibre also recorded high scores for overall acceptance [24]. The BF values for $50 \%$ and $100 \%$ are significantly higher $(\mathrm{p}<0.05)$ compared to JF, which indicates the consumers preferred breadfruit more as the fat replacer in the chicken patties.

\section{Conclusion}

The production of chicken patties with the replacement of fat by using jackfruit and breadfruit as fat replacer had influenced some physicochemical properties such as WHC, cooking yield, colour, texture as well as the proximate analysis of chicken patties. The BF $(100 \%)$ chicken patties showed good results in WHC and cooking yield compared to other samples. Besides, BF in $100 \%$ concentration also obtained positive data in moisture content and protein. It also has reduced the fat content in chicken patties significantly compared to other samples. For colour measurement, BF $(100 \%)$ showed high value of $L^{*}($ lightness) and $\mathrm{b}^{*}$ (yellowness). Texture profile analysis of BF (100\%) showed a good result in terms of hardness, cohesiveness, springiness, and chewiness. In sensory evaluation, BF (100\%) influenced the con- sumer acceptance due to its high score of overall acceptability in sensory properties. In summary, the collected data shows that the replacement of fat by jackfruit and breadfruit at different concentrations was able to improve the physicochemical, texture, and sensory properties in producing low-fat chicken patties. However, the result showed $\mathrm{BF}$ in $100 \%$ concentration can be considered as the best fat replacer in this study and has the potential to be commercialised as low-fat product.

\section{Acknowledgement}

The authors thank Geran Putra - Insentif Putra Muda (GPIPM/2016/9514500) Universiti Putra Malaysia for the financial support.

\section{References}

[1] Nath PM, Kumar V, Praveen PK, \& Ganguly S (2016), Effect of chicken skin, soy protein and olive oil on quality characteristics of chicken nuggets. International Journal of Science, Environment and Technology 5(3), 1574-1585.

[2] Ibrahim FN, Ismail-Fitry MR, Yusoff MM, \& Shukri R (2018) Effects of Fish Collagen Hydrolysate $(\mathrm{FCH})$ as Fat Replacer in the Production of Buffalo Patties. Journal of Advanced Research in Applied Sciences and Engineering Technology 11(1), 108-117.

[3] Wen MCY, Ismail-Fitry MR, Mustapha NA, Hanani ZAN (2018) Effects of Brine Concentration, Thickness and Microwave Finish Drying on the Textural Characteristics of Buffalo Jerky. Journal of Advanced Research Design 46(1), 14-22.

[4] Aslinah LNF, Yusoff MM, \& Ismail-Fitry MR (2018). Simultaneous use of adzuki beans (Vigna angularis) flour as meat extender and fat replacer in reduced-fat beef meatballs (bebola daging). Journal of food science and technology 55(8), 3241-3248.

[5] Mallika EN, Prabhakar K \& Reddy PM (2009). Low Fat Meat Products-An Overview. Veterinary World 2(9), 364-366.

[6] Kirchner JM, Beasley LC, Harris KB, \& Savell JW (2000). Evaluating the cooking and chemical characteristics of low-fat ground beef patties. Journal of Food Composition and Analysis 13(3), 253 264.

[7] Keeton JT (1994). Low-fat meat products - technological problems with processing. Meat Science 36(1-2), 261-276.

[8] Aktaş N \& Genccelep H (2006). Effect of starch type and its modifications on physicochemical properties of bologna-type sausage produced with sheep tail fat. Meat Science 74(2), 404-408.

[9] Furlán LTR, Padilla AP \& Campderrós ME (2014). Development of reduced fat minced meats using inulin and bovine plasma proteins as fat replacers. Meat Science 96(2), 762-768.

[10] Choi YS, Choi JH, Han DJ, Kim HY, Lee MA, Kim HW, \& Kim C J (2009). Characteristics of low-fat meat emulsion systems with pork fat replaced by vegetable oils and rice bran fiber. Meat science 82(2), 266-271.

[11] Dosh KS, Tawfiq NN \& Jabbar SH (2016). Preparation of modified chicken burger by partial replacement of chicken meat with powdered of oyster mushroom and study it is physical and sensory properties. The Iraqi Journal of Agricultural Science 47(7-special issue), 138-143.

[12] Guedes-Oliveira JM, Salgado RL, Costa-Lima BR, GuedesOliveira J \& Conte-Junior CA (2016). Washed cashew apple fiber (Anacardium occidentale L.) as fat replacer in chicken patties. LWT-Food Science and Technology 71, 268-273.

[13] AOAC International (2012). Official method of analysis of AOAC International, 19th edn. AOAC International, Gaithersburg.

[14] Calliari CM, de Souza EL, Castro-Goméz RJH, Honório VG \& Magnani M. (2015). Characterisation and microstructure of reduced-fat chicken patties made with a novel polymer from Agrobacterium radiobacter k84. Food Chemistry 173, 1150-1157.

[15] Brewer MS (2014) Chemical and physical characteristics of meat | Water-holding capacity. In 'Encyclopedia of meat sciences'. 2nd edn. 274-282.

[16] Glicksman M (1991). Hydrocolloids and search for the" Oily Grail". Food Technology October, 94-103.

[17] Mudgil D \& Barak S (2013). Composition, properties and health benefits of indigestible carbohydrate polymers as dietary fiber: a review. International Journal of Biological Macromolecules 61, 16. 
[18] Food Act 1983 and Food Regulations 1985 (2014). International Law Book Services, Petaling Jaya.

[19] Verma AK, Singh VP \& Pathak V (2015). Effect of jackfruit supplement and ageing on the Physico-chemical, texture and sensory characteristics of Chevon patties. Journal of Applied Animal Research 43(3), 247-255.

[20] Beyer R (2007, April). Breadfruit as a candidate for processing. In I International Symposium on Breadfruit Research and Development 757 (209-214).

[21] Sáyago-Ayerdi SG, Brenes A \& Goñi I (2009). Effect of grape antioxidant dietary fiber on the lipid oxidation of raw and cooked chicken hamburgers. LWT-Food Science and Technology 42(5), 971-976

[22] Verma AK, Chatli MK, Kumar D, Kumar P \& Mehta N (2015) Efficacy of sweet potato powder and added water as fat replacer on the quality attributes of low-fat pork patties. Asian-Australasian Journal of Animal Sciences 28(2), 252.

[23] Jalal H, Para PA, Ganguly S, Padhy A, Praveen PK \& Wakchaure, R (2015). Fat replacers in meat: a brief review. World Journal of Engineering Research and Technology 1(2), 16-21.

[24] Fernández-López J, Sendra E, Sayas-Barberá E, Navarro C \& Pérez-Alvarez JA. (2008). Physico-chemical and microbiological profiles of "salchichón"(Spanish dry-fermented sausage) enriched with orange fiber. Meat Science 80(2), 410-417. 